\title{
Macro and Trace Element Levels of Macroalgae Cystoseira foeniculacea and Gongolaria montagnei Species from Mediterranean Region (Antalya/Turkey)
}

\author{
Baran ASSIKKUTLU ${ }^{1 *} \quad$ Emine Sükran OKUDAN ${ }^{2}$ \\ ${ }^{1 *}$ Selçuk University, Faculty of Science, Department of Biology, Konya, Turkey \\ ${ }^{2}$ Akdeniz University, Faculty of Aquaculture, Department of Marine Biology, Antalya, Turkey
}

Geliş/Received: 10.06 .2021

Kabul/Accepted: 14.11 .2021

Yayın/Puplished: 31.12 .2021

How to cite: Aşıkkutlu, B. \& Okudan, E.Ş. (2021). Macro and Trace Element Levels of Macroalgae Cystoseira foeniculacea and Gongolaria montagnei Species from Mediterranean Region (Antalya/ Turkey). J. Anatolian Env. and Anim. Sciences, 6(4), 757-764.

Atıf yapmak için: Așıkkutlu, B. \& Okudan, E.Ş. (2021). Akdeniz Bölgesi' nden (Antalya/ Türkiye) Alınan Makroalg Cystoseira foeniculacea ve Gongolaria montagnei Türlerinin Makro ve İz Element Seviyeleri. Anadolu Çev. ve Hay. Dergisi, 6(4), 757-764.

https://orcid.org/0000-0003-2532-5517 https://orcid.org/0000-0001-5309-7238
*Corresponding author's: Baran AȘIKKUTLU

Selçuk University, Faculty of Science,

Department of Biology, Konya, Turkey

凶: baranasikkutlu@selcuk.edu.tr

\begin{abstract}
Aquatic ecosystems and algae, which are the primary producers living in these areas, are the subject of many studies due to their importance. Macroalgae are indicator organisms in terms of showing the elemental composition of the region they live in. In this study, elemental analyzes of macroalgae belonging to Cystoseira foeniculacea and Gongolaria montagnei were carried out, that species collected from the coastal region of Antalya Province Serik District, which has a coast to the Mediterranean and Pearson Correlation Index (PCI) was applied to show the relationships between the results. The obtained data were compared with other studies. About macro elements, the highest value was determined as $\mathrm{K}$ element and the lowest value was determined as $\mathrm{P}$ element in Cystoseira foeniculacea and Gongolaria montagnei species. About trace elements, for Cystoseira foeniculacea species the highest value as Fe element and the lowest value as Mo element, for Gongolaria montagnei species the highest value as Fe element, and the lowest value as Cd element, were determined. According to the Pearson Correlation Index analysis, positive and negative relationships were determined between the elements. When the data obtained in our study were compared with the data of other previous studies, it was determined that the results were similar to each other.
\end{abstract}

\section{Akdeniz Bölgesi’ nden (Antalya/ Türkiye) Alınan Makroalg Cystoseira foeniculacea ve Gongolaria montagnei Türlerinin Makro ve İz Element Seviyeleri}

\author{
*Sorumlu yazar: \\ Baran ASIKKUTLU \\ Selçuk Üniversitesi, Fen Fakültesi, Biyoloji \\ Bölümü, Konya, Türkiye \\ 凶: baranasikkutlu@selcuk.edu.tr
}

Öz: Sucul ekosistemler ve bu alanlarda yaşayan birincil üretici durumundaki algler, bu önemleri nedeniyle çok sayıda araştırmaya konu olmaktadır. Yaşadıkları alanın element kompozisyonunu göstermesi açısından makroalgler indikatör organizmalardır. Çalışmamızda, Akdeniz' e kıyısı olan Antalya İli Serik İlçesi kıyı bölgesinden toplanan Cystoseira foeniculacea ve Gongolaria montagnei türlerine ait makroalglerin element analizleri yapılmıştır ve sonuçların birbirleriyle olan ilişkilerini göstermek amaçlı Pearson Korelasyon İndeksi (PCI) uygulanmıştır. Elde edilen veriler yapılan diğer çalışmalarla kıyaslanmıştır. Makro elementler için Cystoseira foeniculacea ve Gongolaria montagnei türlerinde en yüksek değer $\mathrm{K}$ elementinde, en düşük değer $\mathrm{P}$ elementinde tespit edilmiştir. İz elementler için Cystoseira foeniculacea türünde en yüksek değer Fe elementinde, en düşük değer Mo elementinde, Gongolaria montagnei türünde en yüksek değer Fe elementinde, en düşük değer Cd elementinde tespit edilmiştir. Pearson Korelasyon İndeks analizine göre elementler arasında pozitif ve negatif yönde ilişkiler belirlenmiştir. Çalışmamızda elde edilen veriler daha önce gerçekleştirilen diğer çalışmaların verileriyle kıyaslandığında, sonuçların birbirleriyle benzerlik gösterdiği belirlenmiştir. 


\section{INTRODUCTION}

Pollution pressures occur in the marine environment, especially in areas with urban and industrial interactions (Bonanno et al., 2020). Elimination of this pollution is time consuming and expensive. The use of lowcost eco-friendly technologies to grade contaminated water sources is an important issue (Ahmadpour, 2012). Heavy metals can be found in natural conditions, but it is important to determine the difference between anthropogenic pollution and natural levels in order to determine the pollution level in the environment (Akcalı \& Küçüksezgin, 2011). Heavy metals cause health problems for living creatures in the environment due to their high toxicity, cause problems in the food chain and reduce environmental quality (Cheng et al., 2019). It is important to compare chemicals in natural sources and sources under anthropogenic pressure. Examining the creatures living in the marine environment is important in terms of showing the effect of pollutants (Chakraborty et al., 2014). Metals found in environment need to be constantly monitored, evaluated and investigated. (Haghshenas et al., 2020). Since the examination of elemental accumulation in ecological environments is an important issue, many researchers are working in this field. (Al-Homaidan et al., 2021; Gümüş et al., 2021; Lin et al., 2020).

Brown algae are considered as a bioindicator of heavy metal presence in coastal waters. Comparing algae which living in different environmental conditions will guide the understanding of the environmental adaptation of these creatures against human influence (Ryabushko et al., 2017). In the coastal region where the sea and land meet, it is seen that there is an anthropogenic pressure due to the increase in the human population. Brown macroalgae belonging to the Cystoseira genus in the coastal region of the Mediterranean, support to the ecosystem with their high biodiversity and productivity (De La Fuente et al., 2019). In recent years, it has been observed that the Cystoseira genus macroalgae has decreased due to the increasing pollution in the Mediterranean (Sales et al., 2011). Algae can accumulate low levels of heavy metals and cause them to be transmitted through the food chain (Pinto et al., 2003). In addition, studies on aquaculture applications and use of macroalgae as a supplementary food source for humans or other creatures according to their biological content have recently been a remarkable field of study (Asghari, 2017; Berik, 2019; Wells, 2017; Yulianto, 2017).

Turkey's Mediterranean coasts are under the influence of eutrophication and pollution problems, especially from agriculture (Muhammed, 2020). Macroalgae has been defined as one of the biological quality elements used to define the ecological quality status of coastal waters in Directive 2000/60/EC of the European Parliament and of the Council (EU, 2000). In our study, the brown macroalgae Cystoseira foeniculacea f. latiramosa (Ercegovic) A. Gómez Garreta, M.C. Barceló, M.A. Ribera \& J.R. Lluch 2001 and Gongolaria montagnei (J.Agardh) Kuntze 1891 species taken in 2015 from the coastal region of Serik District of Antalya Province on the Mediterranean coast were investigated in order to determine their macro and trace element levels. The aim of our study is to evaluate the element accumulation levels by comparing the element levels detected in macroalgae taken from the region determined on the Antalya coast with the results of other studies. In addition, determining the elemental levels of macroalgae species in our study will be a supportive research for studies evaluating the use of these organisms as nutritional supplements.

\section{MATERIAL AND METHOD}

Working Area: The province of Antalya, which is our study area, is located in the southwest of Turkey and is a developed region in terms of tourism activities. Our station where the samples were collected is within the borders of Serik District and is located at $36^{\circ} 49^{\prime} 59.84^{\prime \prime} \mathrm{N}$ and $31^{\circ} 7 ' 28.67 " \mathrm{E}$ coordinates. The satellite image of the sampling station and the region is shown in Figure 1.

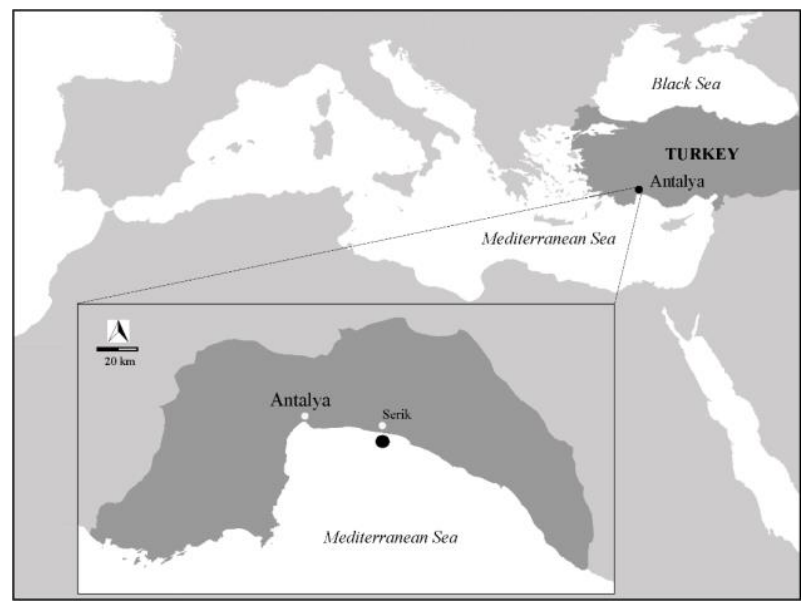

Figure 1. The satellite image of the sampling station and the region.

Collection and Identification of macroalgae: Both algae samples were collected in 2015 from the station determined in the Antalya coastal region during the periods when algae were intense. Collected samples were placed in sterile glass bottles and brought to the laboratory. Morphological identification was made with a light microscope. Algaebase site (Guiry \& Guiry, 2021), study of Orlando-Bonaca \& Trkov, (2020) and Sellam et al., (2017) were used for species identification of macroalgae. Gongolaria montagnei (J.Agardh) Kuntze 1891 species was 
evaluated as a basionym of Cystoseira montagnei J.Agardh species (Guiry \& Guiry, 2021).

\section{Determination of macro and trace elements:}

Cystoseira foeniculacea and Gongolaria montagnei species were first thoroughly washed with tap water, then all epiphytes, organic and mineral particles were manually removed. Samples were rinsed with distilled water and ultrapure water, respectively, then dried in an oven at $45{ }^{\circ} \mathrm{C}$ and stored in airtight boxes at room temperature until analysis (Akköz et al., 2011).

Before analysis, algae samples were placed in durable glass bottles and dried at $105^{\circ} \mathrm{C}$ for 24 hours in a drying oven. $0.2 \mathrm{~g}$ of the dried samples were taken and $5 \mathrm{~mL}$ nitric acid $\left(65 \% \mathrm{HNO}_{3}\right)$ and $2 \mathrm{~mL}$ of purified water were added and allowed to stand at room temperature for 24 hours. After that samples were dissolved in microwaved. Following this process, the samples were placed in the Cem brand Mars 6 model microwave and dissolved at $180^{\circ} \mathrm{C}$ for 45 minutes. The samples removed from the microwave were cooled and filtered through a $100 \mathrm{~mm}$ blue band filter paper, then transferred to falcon tubes and $25 \mathrm{~mL}$ volume was completed with deionized water (Ahmad et al., 2021; Akköz et al., 2011; Cengiz et al., 2017). Three measurement of macro and trace element concentrations were determined using inductively coupled plasma optical emission spectrometer (ICP-OES, Varian Vista) according to DIN EN ISO 11885. (DIN EN ISO 11885, 2009). The wavelengths of the elements measured in the device are respectively B 249.772 nm, Ca 317.933 nm, Cd 214.439 nm, Co 238.892 nm, Cr 267.716 nm, Cu 327.395 nm, Fe 238.204 nm, K 766.491 nm, Mg $279.553 \mathrm{~nm}$, Mn $257.610 \mathrm{~nm}$, Mo $202.032 \mathrm{~nm}$, Na 589.592 nm, Ni 231.604 nm, P 213.618 nm, Pb 220.353 nm and $\mathrm{Zn} 213.857 \mathrm{~nm}$.

Statistical analysis: Pearson Correlation Index (PCI) SPSS 22 package program was used to evaluate the relationship between the parameters. (Öztürk \& Akköz, 2014).

\section{RESULTS}

The macro and trace element minimum, maximum, average values and standart deviations of the ICP device measurement results of Cystoseira foeniculacea and Gongolaria montagnei brown macroalgae samples collected from the coastal region of Antalya Province Serik District in August 2015 are given in Table 1.

Table 1. Macro elements and trace elements ( $\mathrm{mg} \mathrm{kg}^{-1}$ dry weight) minimum, maximum and average values of macroalgae.

\begin{tabular}{|c|c|c|c|c|c|c|}
\hline \multirow[b]{2}{*}{ Macro Elements } & \multicolumn{3}{|c|}{ Cystoseira foeniculacea } & \multicolumn{3}{|c|}{ Gongolaria montagnei } \\
\hline & Minimum & Maximum & Average & Minimum & Maximum & Average \\
\hline $\mathrm{Ca}$ & 7099.65 & 8279.70 & $7841.88 \pm 527.66$ & 9109.93 & 13095.07 & $11233.37 \pm 1637.42$ \\
\hline $\mathrm{K}$ & 27026.02 & 31020.53 & $28974.58 \pm 1632.21$ & 22259.83 & 23230.92 & $22714.83 \pm 398.79$ \\
\hline $\mathrm{Mg}$ & 606.77 & 648.62 & $630.78 \pm 17.63$ & 594.67 & 646.09 & $622.00 \pm 21.12$ \\
\hline $\mathrm{Na}$ & 6140.36 & 6892.86 & $6462.15 \pm 316.72$ & 8104.28 & 8647.02 & $8357.51 \pm 223.05$ \\
\hline $\mathrm{P}$ & 311.24 & 327.82 & $316.84 \pm 7.76$ & 335.11 & 401.19 & $370.35 \pm 27.16$ \\
\hline Trace Elements & Minimum & Maximum & Average & Minimum & Maximum & Average \\
\hline $\mathrm{B}$ & 70.69 & 81.20 & $77.00 \pm 4.54$ & 96.57 & 128.81 & $113.29 \pm 13.19$ \\
\hline $\mathrm{Co}$ & 0.98 & 1.00 & $1.00 \pm 0.01$ & 0.97 & 1.00 & $0.98 \pm 0.01$ \\
\hline $\mathrm{Cr}$ & 0.98 & 1.00 & $1.00 \pm 0.01$ & 0.97 & 1.99 & $1.64 \pm 0.47$ \\
\hline $\mathrm{Cu}$ & 1.96 & 2.01 & $1.66 \pm 0.46$ & 5.81 & 6.97 & $6.22 \pm 0.63$ \\
\hline $\mathrm{Fe}$ & 225.34 & 343.86 & $289.88 \pm 48.96$ & 467.80 & 865.11 & $667.72 \pm 162.21$ \\
\hline Mn & 21.03 & 24.06 & $22.56 \pm 1.24$ & 37.77 & 53.76 & $46.17 \pm 6.55$ \\
\hline Mo & $\mathrm{BDL}$ & BDL & BDL & 0.78 & 0.80 & $0.79 \pm 0.01$ \\
\hline $\mathrm{Ni}$ & 0.98 & 2.01 & $1.33 \pm 0.48$ & 2.91 & 4.98 & $3.93 \pm 0.85$ \\
\hline $\mathrm{Pb}$ & 6.87 & 8.02 & $7.30 \pm 0.51$ & 7.75 & 9.96 & $8.84 \pm 0.90$ \\
\hline $\mathrm{Zn}$ & 2.95 & 4.01 & $3.32 \pm 0.49$ & 5.81 & 7.96 & $6.87 \pm 0.88$ \\
\hline
\end{tabular}

For the Cystoseira foeniculacea species, the highest value among the macro elements was determined as $28974.58 \mathrm{mg} \mathrm{kg}^{-1}$ for the element $\mathrm{K}$ and the lowest value was determined as $316.84 \mathrm{mg} \mathrm{kg}^{-1}$ for the $\mathrm{P}$ element. Among the trace elements of the same species, the highest value was found to be $289.88 \mathrm{mg} \mathrm{kg}^{-1}$ for Fe element, and the lowest value was $0.80 \mathrm{mg} \mathrm{kg}^{-1}$ for Cd elements, and the Mo element was determined below the device measurement range. The macro elements detected in the species are listed as $\mathrm{K}>\mathrm{Ca}>\mathrm{Na}>\mathrm{Mg}>\mathrm{P}$ from largest to smallest. Trace elements detected in the species are listed as $\mathrm{Fe}>\mathrm{B}>\mathrm{Mn}>\mathrm{Pb}>\mathrm{Zn}>\mathrm{Cu}>\mathrm{Ni}>\mathrm{Co}=\mathrm{Cr}>\mathrm{Cd}>\mathrm{Mo}$ from largest to smallest. For Gongolaria montagnei species, the highest value among macro elements was determined as 22714.83 $\mathrm{mg} \mathrm{kg}^{-1}$ for $\mathrm{K}$ element and the lowest value was $370.35 \mathrm{mg}$ $\mathrm{kg}^{-1}$ for $\mathrm{P}$ element. Among the trace elements of the same species, the highest value was $667.72 \mathrm{mg} \mathrm{kg}^{-1}$ for Fe element, and the lowest value was $0.79 \mathrm{mg} \mathrm{kg}^{-1}$ for $\mathrm{Mo}$ and the $\mathrm{Cd}$ element was determined below the device measurement range. The macro elements detected in the species are listed as $\mathrm{K}>\mathrm{Ca}>\mathrm{Na}>\mathrm{Mg}>\mathrm{P}$ from largest to smallest. Trace elements detected in the species are listed as $\mathrm{Fe}>\mathrm{B}>\mathrm{Mn}>\mathrm{Pb}>\mathrm{Zn}>\mathrm{Cu}>\mathrm{Ni}>\mathrm{Cr}>\mathrm{Co}>\mathrm{Mo}>\mathrm{Cd}$ from largest to smallest.

The results of the Pearson Correlation Index analysis applied to show the relationships and correlations of the parameters determined in the algae samples as a result of the ICP analysis are given in Table 2 . 
Table 2. The relationships between parameters determined in algae samples according to Pearson Correlation Index analysis

\begin{tabular}{|c|c|c|c|c|c|c|c|c|c|c|c|c|c|c|c|c|}
\hline & $\mathrm{Ca}$ & $\mathrm{K}$ & $\mathrm{Mg}$ & B & $\mathrm{Na}$ & $\mathrm{P}$ & $\mathrm{Cr}$ & $\mathrm{Cu}$ & $\mathrm{Fe}$ & Mn & $\mathrm{Ni}$ & $\mathrm{Pb}$ & $\mathrm{Zn}$ & $\mathrm{Cd}$ & Co & Mo \\
\hline $\mathrm{Ca}$ & 1 & & & & & & & & & & & & & & & \\
\hline $\mathrm{K}$ & $-0.825^{*}$ & 1 & & & & & & & & & & & & & & \\
\hline $\mathrm{Mg}$ & 0.22 & 0.33 & 1 & & & & & & & & & & & & & \\
\hline B & 0.46 & -0.8 & -0.4 & 1 & & & & & & & & & & & & \\
\hline $\mathrm{Na}$ & 0.71 & $-0.876^{*}$ & -0.2 & $0.945^{* * *}$ & 1 & & & & & & & & & & & \\
\hline $\mathrm{P}$ & $0.987^{* *}$ & -0.8 & 0.3 & 0.47 & 0.71 & 1 & & & & & & & & & & \\
\hline $\mathrm{Cr}$ & $0.933^{* *}$ & -0.6 & 0.4 & 0.33 & 0.56 & $0.942^{* *}$ & 1 & & & & & & & & & \\
\hline $\mathrm{Cu}$ & $0.893^{*}$ & $-0.966^{* *}$ & -0.1 & 0.79 & $0.926^{* *}$ & $0.872^{*}$ & 0.74 & 1 & & & & & & & & \\
\hline $\mathrm{Fe}$ & $0.996^{* *}$ & $-0.842^{*}$ & 0.2 & 0.51 & 0.75 & $0.990^{* *}$ & $0.912^{*}$ & $0.918^{* *}$ & 1 & & & & & & & \\
\hline $\mathrm{Ni}$ & $0.966^{* *}$ & $-0.843^{*}$ & 0.2 & 0.62 & $0.835^{*}$ & $0.978^{* *}$ & $0.870^{*}$ & $0.939^{* *}$ & $0.982^{* * *}$ & $0.982^{* *}$ & 1 & & & & & \\
\hline $\mathrm{Pb}$ & $0.948^{* *}$ & -0.7 & 0.5 & 0.4 & 0.68 & $0.978^{* *}$ & $0.880^{*}$ & $0.814^{*}$ & $0.956^{* *}$ & $0.908^{*}$ & $0.962^{* *}$ & 1 & & & & \\
\hline $\mathrm{Zn}$ & $0.951^{* *}$ & $-0.879^{*}$ & 0.1 & 0.69 & $0.880^{*}$ & $0.959^{* *}$ & $0.848^{*}$ & $0.966^{* *}$ & $0.971^{* *}$ & $0.990^{* *}$ & $0.994^{* *}$ & $0.928^{* *}$ & 1 & & & \\
\hline $\mathrm{Cd}$ & -0.8 & $0.918^{* *}$ & 0.2 & $-0.883^{*}$ & $-0.962^{* *}$ & -0.8 & -0.7 & $-0.970^{* *}$ & $-0.839^{*}$ & $-0.926^{* *}$ & $-0.884^{*}$ & -0.7 & $-0.928^{* *}$ & 1 & & \\
\hline Co & -0.2 & 0.66 & $0.902^{*}$ & -0.7 & -0.6 & -0.1 & -0 & -0.5 & -0.2 & -0.3 & -0.2 & 0.07 & -0.3 & 0.55 & 1 & \\
\hline Mo & 0.81 & $-0.933^{* *}$ & -0.2 & $0.885^{*}$ & $0.962^{* *}$ & 0.8 & 0.69 & $0.974^{* *}$ & $0.838^{*}$ & $0.924^{* *}$ & $0.879^{*}$ & 0.72 & $0.924^{* *}$ & $-0.999^{* *}$ & -0.6 & 1 \\
\hline
\end{tabular}

\section{DISCUSSION AND CONCLUSION}

When we compared the data obtained in our study with other studies, calcium from the macro elements was determined as $7.84 \mathrm{mg} \mathrm{g}^{-1}$ in Cystoseira foeniculacea species and $11.23 \mathrm{mg} \mathrm{g}^{-1}$ in Gongolaria montagnei species in our study. In the study of Szelag-Sikora et al., (2016) the highest mean value for calcium in the Cystoseira barbata species was determined as $24.83 \mathrm{mg} \mathrm{g}^{-1}$ at Striletska station and the lowest value was $9.03 \mathrm{mg} \mathrm{g}^{-1}$ at Sevastopolska station. In the study of Kravtsova et al., (2014) the highest mean value for calcium in the Cystoseira barbata species was $21.10 \mathrm{mg} \mathrm{g}^{-1}$ in the spring, $22.60 \mathrm{mg} \mathrm{g}^{-1}$ in the summer, the highest mean value in the Cystoseira crinita species was $18.10 \mathrm{mg} \mathrm{g}^{-1}$ in the spring, $34.10 \mathrm{mg} \mathrm{g}^{-1}$ in the summer. The data obtained in our study was found to be similar to this study.

Potassium was found to be as $28.97 \mathrm{mg} \mathrm{g}^{-1}$ in Cystoseira foeniculacea species and $22.71 \mathrm{mg} \mathrm{g}^{-1}$ in Gongolaria montagnei species in our study. In the study of Szelag-Sikora et al., (2016) the highest mean value for potassium in the Cystoseira barbata species was determined as $53.22 \mathrm{mg} \mathrm{g}^{-1}$ at Kamyshova station, and the lowest value was $19.91 \mathrm{mg} \mathrm{g}^{-1}$ at Pivdenna station. Kravtsova et al., (2014) found that the highest mean value for potassium in Cystoseira barbata species was $45.40 \mathrm{mg}$ $\mathrm{g}^{-1}$ in spring, $22.60 \mathrm{mg} \mathrm{g}^{-1}$ in summer, the highest mean value in Cystoseira crinita species was $53.70 \mathrm{mg} \mathrm{g}^{-1}$ in spring and $46.70 \mathrm{mg} \mathrm{g}^{-1}$ in summer. The data obtained in our study was found to be similar to this study.

Magnesium was found to be as $0.63 \mathrm{mg} \mathrm{g}^{-1}$ in Cystoseira foeniculacea species and $0.62 \mathrm{mg} \mathrm{g}^{-1}$ in Gongolaria montagnei species in our study. In the study of Szelag-Sikora et al., (2016) the highest mean value for magnesium in the Cystoseira barbata species was determined as $6.26 \mathrm{mg} \mathrm{g}^{-1}$ at Kamyshova station and the lowest value as $4.70 \mathrm{mg} \mathrm{g}^{-1}$ at Pishchana station. In the study of Kravtsova et al., (2014) the highest mean value for magnesium in Cystoseira barbata species was $6.90 \mathrm{mg} \mathrm{g}^{-1}$ in spring, $9.30 \mathrm{mg} \mathrm{g}^{-1}$ in summer, the highest average value in Cystoseira crinita species was $8.70 \mathrm{mg} \mathrm{g}^{-1}$ in spring and
$12.10 \mathrm{mg} \mathrm{g}^{-1}$ in summer, were detected. The data obtained in our study was found to be lower than in these studies.

Sodium was determined as $6.46 \mathrm{mg} \mathrm{g}^{-1}$ in Cystoseira foeniculacea species and $8.36 \mathrm{mg} \mathrm{g}^{-1}$ in Gongolaria montagnei species in our study. Kravtsova et al., (2014) found that the highest mean value for sodium in Cystoseira barbata species was $11.30 \mathrm{mg} \mathrm{g}^{-1}$ in spring, $26.60 \mathrm{mg} \mathrm{g}^{-1}$ in summer, and the highest average value for sodium in Cystoseira crinita species was $20.00 \mathrm{mg} \mathrm{g}^{-1}$ in spring and $25.30 \mathrm{mg} \mathrm{g}^{-1}$ in summer. The data obtained in our study was found to be slightly lower than in these studies.

Phosphorus was detected as $0.32 \mathrm{mg} \mathrm{g}^{-1}$ in Cystoseira foeniculacea species and $0.37 \mathrm{mg} \mathrm{g}^{-1}$ in Gongolaria montagnei species in our study. In the study of Szelag-Sikora et al., (2016) the highest mean value for phosphorus in the Cystoseira barbata species was determined as $1.24 \mathrm{mg} \mathrm{g}^{-1}$ at Sevastopolska station, and the lowest value was $0.47 \mathrm{mg} \mathrm{g}^{-1}$ at Striletska station. The data obtained in our study was found to be similar to this study.

When we compared the data obtained in our study with other studies, the trace element boron was found to be as $0.08 \mathrm{mg} \mathrm{g}^{-1}$ in Cystoseira foeniculacea species and 0.11 $\mathrm{mg} \mathrm{g}^{-1}$ in Gongolaria montagnei species in our study. In the study of Ak et al., (2020) the average value for boron in Cystoseira barbata species was determined as $0.02 \mathrm{mg}$ $\mathrm{g}^{-1}$. The data obtained in our study were found to be slightly higher than in this study.

Cobalt was determined as $1.00 \mathrm{mg} \mathrm{kg}^{-1}$ in Cystoseira foeniculacea species and $0.98 \mathrm{mg} \mathrm{kg}^{-1}$ in Gongolaria montagnei species in our study. In the study of Arıc1 et al., (2019) the mean value for cobalt in Cystoseira barbata species was determined as $0.50 \mathrm{mg} \mathrm{kg}^{-1}$, and the mean value for cobalt in Cystoseira crinita species as 0.57 $\mathrm{mg} \mathrm{kg}{ }^{-1}$. The data obtained in our study was found to be similar to this study. In the study of Türkmen \& Aydin (2021) the mean value for cobalt in Cystoseira barbata species was determined at Piraziz station as $1.78 \mathrm{mg} \mathrm{kg}^{-1}$, at Giresun station as $2.70 \mathrm{mg} \mathrm{kg}^{-1}$, at Espiye station as 0.90 $\mathrm{mg} \mathrm{kg}{ }^{-1}$. The data obtained in our study was found to be similar to this study. 
Cadmium was found to be as $0.80 \mathrm{mg} \mathrm{kg}^{-1}$ in Cystoseira foeniculacea species and below the measurement range in Gongolaria montagnei species in our study. In the study of Arici et al., (2019) the mean value for cadmium in Cystoseira barbata species was found to be as $0.20 \mathrm{mg} \mathrm{kg}^{-1}$, and the average value for cadmium in Cystoseira crinita species was $0.23 \mathrm{mg} \mathrm{kg}^{-1}$. In the study of Akcalı \& Küçüksezgin (2011) about Cystoseira sp. mean value for cadmium in the Canakkale/ City region as 0.09 $\mathrm{mg} \mathrm{kg}^{-1}$, in the Çanakkale/ Dardanos region as $0.05 \mathrm{mg} \mathrm{kg}$ 1 , in the İzmir/ Foça region as $0.06 \mathrm{mg} \mathrm{kg}^{-1}$, in the İzmir/ Urla region as $0.08 \mathrm{mg} \mathrm{kg}^{-1}$, in the Marmaris/ Turunç region as $0.09 \mathrm{mg} \mathrm{kg}^{-1}$ were determined. The data obtained in our study were slightly higher than these studies. In the study of Türkmen \& Aydın (2021) the mean value for cadmium in Cystoseira barbata species was determined at Piraziz station as $0.16 \mathrm{mg} \mathrm{kg}^{-1}$, at Giresun station as 0.60 $\mathrm{mg} \mathrm{kg}{ }^{-1}$, at Espiye station as $0.18 \mathrm{mg} \mathrm{kg}^{-1}$. The data obtained in our study was found to be similar to this study.

Chromium was detected as $1.00 \mathrm{mg} \mathrm{kg}^{-1}$ in Cystoseira foeniculacea species and $1.64 \mathrm{mg} \mathrm{kg}^{-1}$ in Gongolaria montagnei species in our study. In the study of Akcalı \& Küçüksezgin (2011) about Cystoseira sp. mean value for chromium in Canakkale/ City region as $2.13 \mathrm{mg}$ $\mathrm{kg}^{-1}$, in Çanakkale/ Dardanos region as $4.76 \mathrm{mg} \mathrm{kg}^{-1}$, in İzmir/ Foça region as $3.29 \mathrm{mg} \mathrm{kg}^{-1}$, in İzmir/ Urla region as $2.65 \mathrm{mg} \mathrm{kg}^{-1}$, in Marmaris/ Turunç region as $1.36 \mathrm{mg} \mathrm{kg}^{-1}$ were determined. The data obtained in our study was found to be similar to this study. In the study of Türkmen \& Aydın (2021) the mean value for chromium in Cystoseira barbata species was determined at Piraziz station as $34.90 \mathrm{mg} \mathrm{kg}^{-1}$, at Giresun station as $34.00 \mathrm{mg} \mathrm{kg}^{-1}$, at Espiye station as $6.81 \mathrm{mg} \mathrm{kg}^{-1}$. The data obtained in our study was found to be similar to this study.

Copper was found to be as $1.66 \mathrm{mg} \mathrm{kg}^{-1}$ in Cystoseira foeniculacea species and $6.22 \mathrm{mg} \mathrm{kg}^{-1}$ in Gongolaria montagnei species in our study. In the study of Aric1 et al., (2019) the mean value for copper in Cystoseira barbata species was $10.20 \mathrm{mg} \mathrm{kg}^{-1}$, and the mean value for copper in Cystoseira crinita species was $4.27 \mathrm{mg} \mathrm{kg}^{-1}$. In the study of Akcalı \& Küçüksezgin (2011) for Cystoseira sp. mean value for copper in the Çanakkale/ City region as $6.73 \mathrm{mg} \mathrm{kg}^{-1}$, in Çanakkale/ Dardanos region as $3.13 \mathrm{mg}$ $\mathrm{kg}^{-1}$, in İzmir/ Foça as $5.29 \mathrm{mg} \mathrm{kg}^{-1}$, in İzmir/ Urla as 2.37 $\mathrm{mg} \mathrm{kg}^{-1}$, in Marmaris/ Turunç region as $5.69 \mathrm{mg} \mathrm{kg}^{-1}$ were determined. The data obtained in our study were similar to the first study, but slightly higher than the second study. In the study of Türkmen \& Aydın (2021) the mean value for copper in Cystoseira barbata species was determined at Piraziz station as $7.11 \mathrm{mg} \mathrm{kg}^{-1}$, at Giresun station as 16.20 $\mathrm{mg} \mathrm{kg}{ }^{-1}$, at Espiye station as $8.40 \mathrm{mg} \mathrm{kg}^{-1}$. The data obtained in our study was found to be similar to this study.
Iron was determined as $0.29 \mathrm{mg} \mathrm{g}^{-1}$ in Cystoseira foeniculacea species and $0.67 \mathrm{mg} \mathrm{g}^{-1}$ in Gongolaria montagnei species in our study. In the study of Aric1 et al., (2019) the mean value for iron in Cystoseira barbata species was $0.48 \mathrm{mg} \mathrm{g}^{-1}$, and the mean value for iron in Cystoseira crinita species was $0.32 \mathrm{mg} \mathrm{g}^{-1}$. In the study of Akcalı \& Küçüksezgin (2011) about Cystoseira sp. mean value for iron in the species as $0.30 \mathrm{mg} \mathrm{g}^{-1}$ in Çanakkale/ City region, $0.19 \mathrm{mg} \mathrm{g}^{-1}$ in Çanakkale/ Dardanos region, $0.10 \mathrm{mg} \mathrm{g}^{-1}$ in İzmir/ Foça region, $230.00 \mathrm{mg} \mathrm{g}^{-1}$ in İzmir/ Urla region, $0.33 \mathrm{mg} \mathrm{g}^{-1}$ in Marmaris/ Turunç region, were determined. The data obtained in our study were slightly higher than these studies. In the study of Türkmen \& Aydın (2021) the mean value for iron in Cystoseira barbata species was determined at Piraziz station as $3,19 \mathrm{mg} \mathrm{g}^{-1}$, at Giresun station as 4,48 $\mathrm{mg} \mathrm{g}^{-1}$, at Espiye station as $1,58 \mathrm{mg}$ $\mathrm{g}^{-1}$. The data obtained in our study was found to be similar to this study.

Manganese was determined as $0.02 \mathrm{mg} \mathrm{g}^{-1}$ in Cystoseira foeniculacea species and $0.05 \mathrm{mg} \mathrm{g}^{-1}$ in Gongolaria montagnei species in our study. In the study of Arıc1 et al., (2019) the mean value for manganese in Cystoseira barbata species was determined as $0.02 \mathrm{mg} \mathrm{g}^{-1}$, and the mean value for manganese in Cystoseira crinita species was determined as $0.03 \mathrm{mg} \mathrm{g}^{-1}$. The data obtained in our study were found to be slightly higher than in this study. In the study of Türkmen \& Aydın (2021) the mean value for manganese in Cystoseira barbata species was determined at Piraziz station as $0,06 \mathrm{mg} \mathrm{g}^{-1}$, at Giresun station as $0,11 \mathrm{mg} \mathrm{g}^{-1}$, at Espiye station as $0,06 \mathrm{mg} \mathrm{g}^{-1}$. The data obtained in our study was found to be similar to this study.

Molybdenum was determined as $0.79 \mathrm{mg} \mathrm{kg}^{-1}$ in Gongolaria montagnei species and below the measurement range in Cystoseira foeniculacea species, in our study. In the study of Ak et al., (2020) the average value for molybdenum in the Cystoseira barbata species was determined as $0.18 \mathrm{mg} \mathrm{kg}^{-1}$. The data obtained in our study were found to be slightly higher than in this study.

Nickel was found to be as $1,33 \mathrm{mg} \mathrm{kg}^{-1}$ in Cystoseira foeniculacea species and $3,93 \mathrm{mg} \mathrm{kg}^{-1}$ in Gongolaria montagnei species in our study. In the study of Arıc1 et al., (2019) the mean value for nickel in Cystoseira barbata species was determined as $4.44 \mathrm{mg} \mathrm{kg}^{-1}$, and the average value for nickel in Cystoseira crinita species was $4.11 \mathrm{mg} \mathrm{kg}^{-1}$. The data obtained in our study was found to be slightly higher than in this study. In the study of Türkmen \& Aydın (2021) the mean value for nickel in Cystoseira barbata species was determined at Piraziz station as $173.00 \mathrm{mg} \mathrm{kg}^{-1}$, at Giresun station as $164.00 \mathrm{mg}$ $\mathrm{kg}^{-1}$, at Espiye station as $31.80 \mathrm{mg} \mathrm{kg}^{-1}$. The data obtained in our study were found to be lower than in this study. 
Lead was found to be as $7.30 \mathrm{mg} \mathrm{kg}^{-1}$ in Cystoseira foeniculacea species and $8.84 \mathrm{mg} \mathrm{kg}^{-1}$ in Gongolaria montagnei species in our study. In the study of Aric1 et al., (2019) the mean value for lead in Cystoseira barbata species was $1.44 \mathrm{mg} \mathrm{kg}^{-1}$, and the mean value for lead in Cystoseira crinita species was $0.87 \mathrm{mg} \mathrm{kg}^{-1}$. In the study of Akcalı \& Küçüksezgin (2011) about Cystoseira sp. mean value for lead in Çanakkale/ City region as 0.01 $\mathrm{mg} \mathrm{kg}{ }^{-1}$, in Çanakkale/ Dardanos region as $0.002 \mathrm{mg} \mathrm{kg}^{-1}$, in İzmir/ Foça region as $0.003 \mathrm{mg} \mathrm{kg}^{-1}$, in Izmir/ Urla region as $0.003 \mathrm{mg} \mathrm{kg}^{-1}$, in Marmaris/ Turunc region as $0.001 \mathrm{mg} \mathrm{kg}^{-1}$ were determined. The data obtained in our study were found to be higher than these studies. In the study of Türkmen \& Aydın (2021) the mean value for lead in Cystoseira barbata species was determined at Piraziz station as $1.51 \mathrm{mg} \mathrm{kg}^{-1}$, at Giresun station as $2.31 \mathrm{mg} \mathrm{kg}^{-1}$, at Espiye station as $1.00 \mathrm{mg} \mathrm{kg}^{-1}$. The data obtained in our study were found to be slightly higher than in this study.

Zinc was found to be as $3.32 \mathrm{mg} \mathrm{kg}^{-1}$ in Cystoseira foeniculacea species and $6.87 \mathrm{mg} \mathrm{kg}^{-1}$ in Gongolaria montagnei species in our study. In the study of Aric1 et al., (2019) the mean value for zinc in Cystoseira barbata species was $59.50 \mathrm{mg} \mathrm{kg}^{-1}$, and the mean value for zinc in Cystoseira crinita species was $47.89 \mathrm{mg} \mathrm{kg}^{-1}$. In the study of Akcalı \& Küçüksezgin (2011) about Cystoseira sp. mean value for zinc in the Canakkale/ City region as 75.50 $\mathrm{mg} \mathrm{kg}{ }^{-1}$, in the Çanakkale/ Dardanos region as $36.90 \mathrm{mg}$ $\mathrm{kg}^{-1}$, in the Izmir/ Foça region as $23.80 \mathrm{mg} \mathrm{kg}^{-1}$, in the İzmir/ Urla region as $40.50 \mathrm{mg} \mathrm{kg}^{-1}$, in the Marmaris/ Turunc region as $51.50 \mathrm{mg} \mathrm{kg}^{-1}$ was determined. The data obtained in our study were found to be similar to these studies. In the study of Türkmen \& Aydın (2021) the mean value for zinc in Cystoseira barbata species was determined at Piraziz station as $24.30 \mathrm{mg} \mathrm{kg}^{-1}$, at Giresun station as $79.50 \mathrm{mg} \mathrm{kg}^{-1}$, at Espiye station as $31.80 \mathrm{mg} \mathrm{kg}^{-}$ 1 . The data obtained in our study were found to be lower than in this study.

According to PCI Table, relations between parameters at 0.05 significance level that, $\mathrm{Ca}$ correlated positive with $\mathrm{Cu}$ and negative with $\mathrm{K}$. K correlated negative with $\mathrm{Ca}, \mathrm{Na}, \mathrm{Fe}, \mathrm{Mn}, \mathrm{Ni}, \mathrm{Zn}$. $\mathrm{Mg}$ correlated positive with Co. B correlated positive with Mo and negative with $\mathrm{Cd}$. $\mathrm{Na}$ correlated positive with $\mathrm{Mn}, \mathrm{Ni}, \mathrm{Zn}$ and negative with $\mathrm{K}$. P correlated positive with $\mathrm{Cu}$. $\mathrm{Cr}$ correlated positive with $\mathrm{Fe}, \mathrm{Mn}, \mathrm{Ni}, \mathrm{Pb}, \mathrm{Zn}$. $\mathrm{Cu}$ correlated positive with $\mathrm{Ca}, \mathrm{P}, \mathrm{Pb}$. Fe correlated positive with $\mathrm{Cr}$, Mo and negative with $\mathrm{Cd}, \mathrm{K}$. Mn correlated positive with $\mathrm{Na}$, $\mathrm{Cr}, \mathrm{Pb}$ and negative with $\mathrm{K}$. Ni correlated positive with $\mathrm{Na}$, $\mathrm{Cr}$, Mo and negative with $\mathrm{Cd}$, K. Pb correlated positive with $\mathrm{Cr}, \mathrm{Cu}, \mathrm{Mn}$. Zn correlated positive with $\mathrm{Na}, \mathrm{Cr}$ and negative with $\mathrm{K}$. Cd correlated negative with $\mathrm{B}, \mathrm{Fe}, \mathrm{Ni}$. Co correlated positive with $\mathrm{Mg}$. Mo correlated positive with B, Fe, Ni. Relations between parameters at 0.01 significance level that, $\mathrm{Ca}$ correlated positive with $\mathrm{P}, \mathrm{Cr}$, $\mathrm{Fe}, \mathrm{Mn}, \mathrm{Ni}, \mathrm{Pb}, \mathrm{Zn}$. K correlated positive with $\mathrm{Cd}$ and negative with $\mathrm{Cu}$, Mo. B correlated positive with $\mathrm{Na}$. Na correlated positive with $\mathrm{Cu}, \mathrm{Mo}, \mathrm{B}$ and negative with $\mathrm{Cd}$. $\mathrm{P}$ correlated positive with $\mathrm{Cr}, \mathrm{Fe}, \mathrm{Mn}, \mathrm{Ni}, \mathrm{Pb}, \mathrm{Zn}, \mathrm{Ca} . \mathrm{Cr}$ correlated positive with $\mathrm{Ca}, \mathrm{P}$. $\mathrm{Cu}$ correlated positive with $\mathrm{Fe}, \mathrm{Mn}, \mathrm{Ni}, \mathrm{Zn}$, Mo, $\mathrm{Na}$ and negative with $\mathrm{Cd}, \mathrm{K}$. Fe correlated positive with $\mathrm{Mn}, \mathrm{Ni}, \mathrm{Pb}, \mathrm{Zn}, \mathrm{Ca}, \mathrm{P}, \mathrm{Cu}$. Mn correlated positive with $\mathrm{Ni}, \mathrm{Zn}, \mathrm{Mo}, \mathrm{Ca}, \mathrm{P}, \mathrm{Cu}, \mathrm{Fe}$ and negative with $\mathrm{Cd}$. Ni correlated positive with $\mathrm{Pb}, \mathrm{Zn}, \mathrm{Ca}$, $\mathrm{P}, \mathrm{Cu}, \mathrm{Fe}, \mathrm{Mn}$. $\mathrm{Pb}$ correlated positive with $\mathrm{Zn}, \mathrm{Ca}, \mathrm{P}, \mathrm{Fe}$, Ni. Zn correlated positive with $\mathrm{Mo}, \mathrm{Ca}, \mathrm{P}, \mathrm{Cu}, \mathrm{Fe}, \mathrm{Mn}, \mathrm{Ni}$, $\mathrm{Pb}$ and negative with $\mathrm{Cd}$. Cd correlated positive with $\mathrm{K}$ and negative with $\mathrm{Mo}, \mathrm{Na}, \mathrm{Cu}, \mathrm{Mn}, \mathrm{Zn}$.

It was determined that the $\mathrm{K}$ element showed the highest positive and negative correlation with other elements at 0.05 significance level and $\mathrm{Zn}$ element showed the highest positive and negative correlation with other elements at 0.01 significance level. In addition, $\mathrm{Mg}$ and $\mathrm{Co}$ elements did not show any correlation with other elements at the 0.01 significance level, also these two elements and the $\mathrm{P}$ element were the elements with the lowest correlation with the other elements at the 0.05 significance level. In another study, according to Gümüş (2021), physicochemical and heavy metals in the Akarçay River were analyzed by PCI and it was stated that they showed positive and negative correlations with each other.

As a result, in our study, Cystoseira foeniculacea and Gongolaria montagnei macroalgae species, which are included in brown algae were collected from the coasts of Antalya Province Serik District, because of they are bioindicators for heavy metals in aquatic ecosystems, Macro and trace element levels of algae were examined using the ICP device and the results were compared with other studies conducted in our country and in the world. In addition, the relations between the measurement results and these results are shown by Pearson Correlation Index analysis. In the macro element analysis of the samples taken from the region constituting our study area, the highest value was determined as $\mathrm{K}$ element and the lowest value as $\mathrm{P}$ element in both Cystoseira foeniculacea species and Gongolaria montagnei species. In the trace element analysis of the samples taken from the region forming our study area, the highest value was found as Fe element and the lowest value as Mo element in Cystoseira foeniculacea species, the highest value as Fe element and the lowest value as Cd element in Gongolaria montagnei species. When the data obtained in our study were evaluated in general, similar results were found in other studies. According to these results, it can be said that there is no intense element accumulation in the study area. 


\section{REFERENCES}

Ahmad, H., Zhao, L., Liu, C., Cai, C. \& Ma, F. (2021). Ultrasound assisted dispersive solid phase microextraction of inorganic arsenic from food and water samples using $\mathrm{CdS}$ nanoflowers combined with ICP-OES determination. Food Chemistry, 338, $128028 . \quad$ DOI: 10.1016/j.foodchem.2020.128028

Ahmadpour, P., Ahmadpour, F., Mahmud, T.M.M., Abdu, A., Soleimani, M. \& Tayefeh, F.H. (2012). Phytoremediation of heavy metals: A green technology. African Journal of Biotechnology, 11(76), 14036-14043. DOI: 10.5897/AJB12.459

Ak, İ., Çankırılıgil, E.C., Türker, G. \& Sever, O. (2020). Assessment of light intensity and salinity regimes on the element levels of brown macroalgae, Treptacantha barbata: Application of response surface methodology (RSM). Food Science and Technology, (AHEAD). DOI: 10.1590/fst.25220

Akköz, C., Arslan, D., Ünver, A., Özcan, M.M. \& Yılmaz, B. (2011). Chemical composition, total phenolic and mineral contents of Enteromorpha intestinalis (L.) Kütz. and Cladophora glomerata (L.) Kütz. seaweeds. Journal of Food Biochemistry, 35(2), 513-523. DOI: 10.1111/j.1745-4514.2010.00399.x

Akcalı, I. \& Küçüksezgin, F. (2011). A biomonitoring study: heavy metals in macroalgae from eastern Aegean coastal areas. Marine Pollution Bulletin, 62(3), 637-645. DOI: 10.1016/j.marpolbul.2010.12.021

Al-Homaidan, A.A., Al-Ghanayem, A.A., Al-Qahtani, H.S., Al-Abbad, A.F., Alabdullatif, J.A., Alwakeel, S.S. \& Ameen, F. (2021). Effect of sampling time on the heavy metal concentrations of brown algae: A bioindicator study on the Arabian Gulf coast. Chemosphere, 263, 127998. DOI: 10.1016/j.chemosphere.2020.127998

Arıcı, E., Bat, L. \& Yıldız, G. (2019). Comparison Of Metal Uptake Capacities Of The Brown Algae Cystoseira barbata and Cystoseira crinita (Phaeophyceae) Collected In Sinop, Turkey. Pakistan Journal of Marine Sciences, 28(1), 0517.

Asghari, S., Salarzadeh, A.R., Rohani, K., Yahyavi, M. \& Mohammadizadeh, F. (2017). Fatty acid profile of wild and farmed sandworms, Perinereis nuntia, in the coast of Bandar Abbas, Iran. Turkish Journal of Fisheries and Aquatic Sciences, 17(5), 1049-1053. DOI: 10.4194/1303-2712-v17_5_21

Berik, N. \& Cankırılıgil, E.C. (2019). The elemental composition of green seaweed (Ulva rigida) collected from Çanakkale, Turkey. Aquatic Sciences and Engineering, 34(3), 74-79. DOI: 10.26650/ASE2019557380

Orlando-Bonaca, M. \& Trkov, D. (2020). After more than forty-five years a new finding of Cystoseira foeniculacea $f$. latiramosa in the coastal sea of Slovenia. Annales, Series Historia Naturalis, 30(2), 233-238. DOI: 10.19233/ASHS.2020.28
Bonanno, G., Veneziano, V. \& Piccione, V. (2020). The alga Ulva lactuca (Ulvaceae, Chlorophyta) as a bioindicator of trace element contamination along the coast of Sicily, Italy. Science of The Total Environment, 699, 134329. DOI: 10.1016/j.scitotenv.2019.134329

Cengiz, M.F., Kilic, S., Yalcin, F., Kilic, M. \& Yalcin, M. G. (2017). Evaluation of heavy metal risk potential in Bogacayi River water (Antalya, Turkey). Environmental monitoring and assessment, 189(6), 248. DOI: 10.1007/s10661017-5925-3

Chakraborty, S., Bhattacharya, T., Singh, G. \& Maity, J.P. (2014). Benthic macroalgae as biological indicators of heavy metal pollution in the marine environments: A biomonitoring approach for pollution assessment. Ecotoxicology and Environmental Safety, 100, 61-68. DOI: 10.1016/j.ecoenv.2013.12.003

Cheng, S.Y., Show, P.L., Lau, B.F., Chang, J.S. \& Ling, T.C. (2019). New prospects for modified algae in heavy metal adsorption. Trends in Biotechnology, 37(11), 1255-1268. DOI: 10.1016/j.tibtech.2019.04.007

De La Fuente, G., Asnaghi, V., Chiantore, M., Thrush, S., Povero, P., Vassallo, P., Petrillo, M. \& Paoli, C. (2019). The effect of Cystoseira canopy on the value of midlittoral habitats in NW Mediterranean, an emergy assessment. Ecological Modelling, $\quad 404, \quad 1-11 . \quad$ DOI: 10.1016/j.ecolmodel.2019.04.005

DIN EN ISO 11885. (2009). Water quality Determination of selected elements by inductively coupled plasma optical emission spectrometry (ICPOES)(ISO 11885: 2007); German version $E N$ ISO, 2009, 11885.

EU. (2000). Directive 2000/60/EC of the European parliament and of the council, of 23 October 2000, establishing a framework for Community action in the field of water policy. Official Journal of the European Communities.

Guiry M.D. \& Guiry G.M. (2021). AlgaeBase. Worldwide electronic publication, National University of Ireland, Galway. http://www.algaebase.org; searched on 06 June 2021.

Gümüş N.E. (2021). Determination Of Water Quality And Heavy Metal Pollution Of Akarçay Stream (Afyonkarahisar). Journal of Anatolian Environmental and Animal Sciences, 6(1), 120127. DOI: $10.35229 /$ jaes. 839147

Gümüş, N. E., Aşıkkutlu B., Kesinkaya, H.B. \& Akköz, C. (2021). Comparison Of Heavy Metal Absorption Of Some Algae Isolated From Altınapa Dam Lake (Konya). Journal of Anatolian Environmental and Animal Sciences, 6(1), 50-56. DOI: 10.35229/jaes.809876

Haghshenas, V., Kafaei, R., Tahmasebi, R., Dobaradaran, S., Hashemi, S., Sahebi, S., Sorial, G.A. \& Ramavandi, B. (2020). Potential of green/brown algae for monitoring of metal (loid) $\mathrm{s}$ pollution in the coastal seawater and sediments of the Persian Gulf: ecological and 
health risk assessment. Environmental Science and Pollution Research, 27(7), 7463-7475. DOI: 10.1007/s11356-019-07481-0

Kravtsova, A., Milchakova, N. \& Frontasyeva, M. (2014). Elemental accumulation in the Black Sea brown algae Cystoseira studied by neutron activation analysis. Ecological Chemistry and Engineering S, 21(1), 9-23. DOI: 10.2478/eces2014-0001

Lin, Z., Li, J., Luan, Y. \& Dai, W. (2020). Application of algae for heavy metal adsorption: A 20-year metaanalysis. Ecotoxicology and Environmental Safety, $\quad 190, \quad 110089 . \quad$ DOI: 10.1016/j.ecoenv.2019.110089

Muhammed, E.A. (2020). The Problem of Environmental Pollution In The Mediterranean Sea Along The Coast of Turkey. Journal of Engineering Studies and Research, 26(2), 7-14.

Öztürk B.Y. \& Akköz, C. (2014). Investigation of water quality of Apa Dam Lake (Çumra-Konya) and according to the evaluation of PCA. Biodicon. 7(2), 136-147.

Pinto, E., Sigaud-Kutner, T.C.S., Leitao, M.A.S., Okamoto, O.K., Morse, D. \& Colepicolo, P. (2003). Heavy metal-induced oxidative stress in algae. Journal of Phycology, 39, 1008-1018.

Ryabushko, V.I., Prazukin, A.V., Gureeva, E.V., Bobko, N.I., Kovrigina, N.P. \& Nekhoroshev, M.V. (2017). Fucoxanthin and heavy metals in brown algae of genus Cystoseira C. Agardh from water areas with different anthropogenic influences (Black Sea). Marine Biological Journal, 2(2), 70-79. DOI: 10.21072/mbj.2017.02.2.07

Sales, M., Cebrian, E., Tomas, F. \& Ballesteros, E. (2011). Pollution impacts and recovery potential in three species of the genus Cystoseira (Fucales, Heterokontophyta). Estuarine, Coastal and Shelf Science, 92(3), 347-357. DOI: 10.1016/j.ecss.2011.01.008

Sellam, L.N., Blanfuné, A., Boudouresque, C.F., Thibaut, T., Zahaf, C.R. \& Verlaque, M. (2017). Cystoseira montagnei J. Agardh and $C$. spinosa Sauvageau (Phaeophyceae, Sargassaceae): A Taxonomic Reappraisal of Misused Names, with the Proposal of Cystoseira michaelae Verlaque et al. nom. et stat. nov. Cryptogamie, Algologie, 38(2), 133-158. DOI: 10.7872/crya/v38.iss2.2017.133

Szelag-Sikora, A., Niemiec, M. \& Sikora, J. (2016). Assessment of the content of magnesium, potassium, phosphorus and calcium in water and algae from the Black Sea in selected bays near Sevastopol. Journal of Elementology, 21(3), 915926. DOI: 10.5601/jelem.2015.20.4.969

Türkmen, M. \& Aydın, T. (2021). Seasonal and Spatial Accumulation of Heavy Metals in Cystoseira barbata from Northeastern Black Sea Coasts. Indian Journal of Geo-Marine Sciences, 50(4), 339-342.
Wells, M.L., Potin, P., Craigie, J.S., Raven, J.A., Merchant, S.S., Helliwell, K.E., Smith, A.G., Camire, M.E. \& Brawley, S. H. (2017). Algae as nutritional and functional food sources: revisiting our understanding. Journal of Applied Phycology, 29(2), 949-982. DOI: 10.1007/s10811-016-0974-5

Yulianto, H., Damai, A.A., Delis, P.C. \& Elisdiana, Y. (2017). Spatial analysis to evaluate the suitability of seaweed farming site in Lampung Bay, Indonesia. Turkish Journal of Fisheries and Aquatic Sciences, 17(6), 1253-1261. DOI: 10.4194/1303-2712-v17_6_18 